\title{
The Compromised Voice: A Consideration of Typography as A Linguistic Expression of Gay Identity in the Silent Film Boy
}

\author{
Welby Ings \\ School of Art \& Design, Auckland University of Technology \\ Private Bag 92006, Auckland 1142, New Zealand. \\ Tel: 0-064-92-9999Ｅ-mail: welby.ings@aut.ac.nz
}

Received: June 4, 2011 Accepted: June 17, 2011 doi:10.5296/ijl.v3i1.776

\begin{abstract}
This paper begins with a brief discussion of interdisciplinary connections between linguistics and typography. It then offers a consideration of how typography used in queer film has been employed to marginalise gay men. In doing so, the article examines recurring typographical profiles in promotional material that reinforce notions of gay men as the other. Within this consideration it locates typographical depictions of the internally discordant, the damaged threat, and the passive-aggressive. In discussing these specific approaches to the typographical depiction of gay men in cinema, the paper traces a development from marginalisation to self-assertion.
\end{abstract}

Set against this discussion, the paper examines how typography designed for the short film boy (Note 1) looked beyond these precedents for inspiration. In doing this, the designer considered themes embedded in the argot of the New Zealand male prostitute. (Note 2) This language form is permeated by themes of detachment and ecclesiasticism. By applying these metaphors to the short film's visual and typographical design, the director discusses how an alternative, distinctive, and arguably more authentic gay voice was created.

The short film boy can be viewed at http://www.nzonscreen.com/title/boy-2004

Keywords: Argot, Metaphor, Male prostitution, Typography 


\section{Introduction}

\subsection{Typography as form}

Much contemporary discussion of typography in film has focused on the role of typographic form in conveying meaning and the contribution of formal elements like leading, kerning, letterform and kinetics to issues of readability and legibility (Bellantoni \& Woolman, 1999 and 2000; Worthington, 1998). While these physical concerns are pertinent to any discussion of meaning, they tend to avoid addressing the wider, contextual concerns relating to the way spaces of cultural inclusion and exclusion are mediated via typographical treatment. Otherness, as presented in the written word, may be considered as not only a construction of word meaning but also a construct of form.

\subsection{Typography and linguistics}

In 1997, when David Crystal noted a "remarkable paucity of typographers who knew anything about linguistics, or the even greater paucity of linguists who knew anything about typography" (p.7), he ignored a small number of writers whose concerns with graphic substance in communication had sought interfaces between these disciplines.

In 1984, Drucker discussed the formal properties of typography in her artist's books and analysed how these expanded the semantic value of a text by configuring it as an image. In 1996, Waller considered approaches taken by linguists (stylistics, discourse analysis, and text linguistics) as methods for defining and describing the functioning nature of typography as a genre. In the same year, Kress and Van Leeuwen published their seminal work that considered type as a form of social semiotics.

In the wake of Crystal's essay, Walker (2001) drew heavily on applied linguistics to discuss, with reference to everyday constructions, the manner in which typography and its visual organisation communicates meaning. In the same year, Salen considered ways in which typography, as a vehicle for social marginalisation, misrepresented minorities by 'languaging' them as exclusive and exotic. Three years later in the dual arenas of typography and paralinguistics, Mealing (2003) developed a system of mappings aimed at exploiting and visually extending the semantic potential of typographical messages. Four years later in 2007, (while still noting a paucity of interdisciplinary exchange), Spitzmüller analysed how typographic features in certain music genres were used to signify the sub-cultural identity.

\subsection{A paucity of exchange}

Traditionally typographers have concentrated on the physical features of printed and spatio-temporal graphic expression, so very rarely does one encounter examples of them discussing how their decision making around typography has been designed to directly influence linguistic meaning. Crystal (1997) suggests this may be in part due to a lack of common vocabulary between the disciplines, and argues that "linguistics texts on the whole ignore typography" (p.7). Waller (1996) suggests that this "exclusion of typography from mainstream linguistics can be seen as a corollary of four major theoretical positions: the 
primary of speech, the restriction of sentence level (not too many typographical events happen within a sentence), the arbitrariness of the linguistic sign, and the linearity of language" ( $p$. 346).

Spitzmüller (2007, p.2) argues that even though these theoretical positions have been reconsidered in recent years, Waller's general judgment may be partially valid for linguistics in Europe and the United States. However, he notes that such assertions may be different in certain Asian countries where iconicity in writing is integral to construction and meaning.(Note 3)

\section{Typography and defining the 'other' in gay film posters}

\subsection{Standardisation and marginalisation}

Typographers have historically created the other in opposition to standardised alphabets. Typefaces used in film title sequences and promotional media, like Interstate, Bell Gothic, Arial, Univers, Century School book, and Times New Roman, have become ubiquitous voices to which we have grown accustomed. Salen (2001) suggests they are utopian and generic, belonging everywhere and nowhere in a mediated, global environment. They have no dialect and no affiliation to region and, as seemingly non-aligned, they have become representations of a graphic form that while inclusive, also acts as a kind of cultural border. It is this cultural border against which typographical representations of gay men have historically been demarcated and defined.

In the early years of film (in print media, title, and key card design) typographical representations of the other were established as existing outside of the dominant order. In cinema, treatments employed to speak about gay men were dislocated from the philosophical and metaphorical constructs of the community of men they purported to represent.

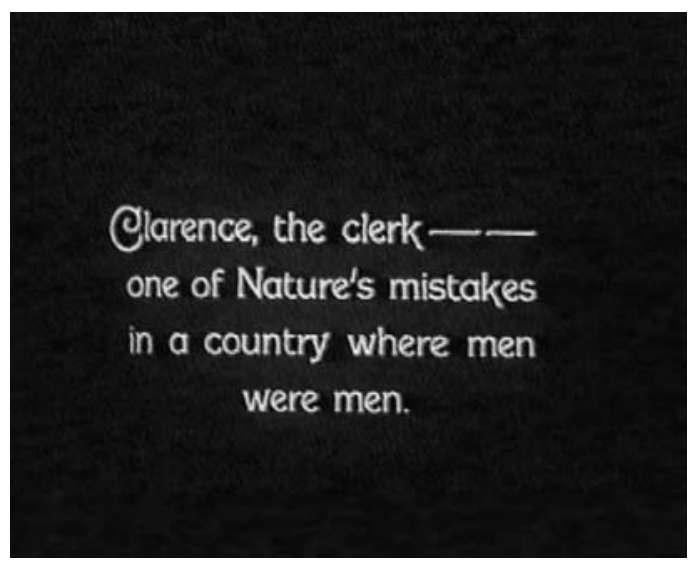

Figure 1. The embellishment of a gay character's name in Robin Williamson's Wanderer of the West (1927) is indicative of the propensity for language and type to become complicit in emphasising the marginal and effeminate nature of gay men in cinema of the period.

These designs were imitations of culture. Because of their exoticised physical form, they came to represent difference as decorative, difficult, and (because they generally, could not 


\section{Macrothink}

International Journal of Linguistics

ISSN 1948-5425

2011, Vol. 3, No. 1: E16

function as readable forms in large bodies of text) impractical. Treatments of gay identity often profiled exaggerations and embellishments that came to represent difference that emphasised cultural marginalisation and reinforcement of stereotypical constructions of ineptitude and otherness. Significantly, decisions regarding the content and design of these cards were rarely those of the film's director. Griffith and Mayer (1971) note that the inclusion of title cards during the era of silent cinema was generally the initiative of producers. The values embedded in them were therefore less influenced by artistic position and more by pragmatism and pandering to perceived audience values of the period.

Historically this treatment of gay men in the typography of film promotion media may be seen in distinctive profiles, three of which are useful in considering the paradigms against which design for the gay voice in boy was considered. These distinctive treatments may be broadly categorised as internal discordance, damaged threat, and passive-aggression.

\subsection{The internally discordant}

By internally discordant I refer to typographical constructions that juxtapose antithetical elements. This technique is designed to destablise a text and signifiy otherness as an intrusion upon conventional order. Because ideas concerning the regularity of language are closely entwined with notions of social order, these typographic constructions exist outside of convention and are designed to incite suspicion or ridicule. They direct the reader to make value judgments about gender, stability, seriousness or cultural safety. Figures 2 and 3 illustrate examples of the technique.

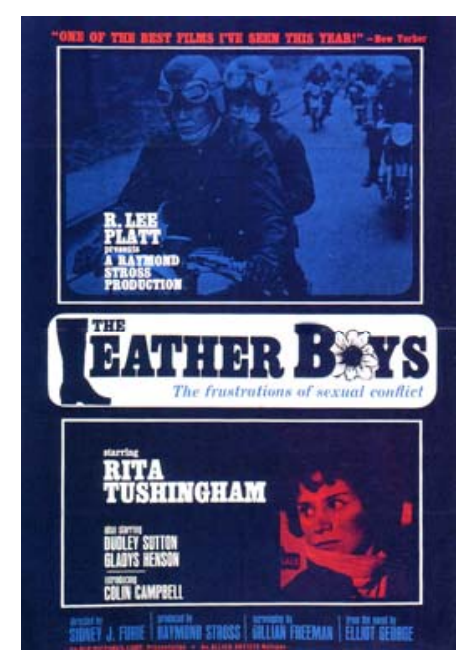

Figure 2. There were several print promotions for Sidney Furie's The Leather Boys (the other notable one being the discordant ad. campaign featuring torn images alongside the tagline "Three lives savagely ripped apart.") The one sheet above, however, uses a title design that snidely suggests that gay bikers might not be 'real men'. It does this by implanting into the masculinised typeface used for the title (Clarendon, 1845), antithetical signifiers of a daisy and a silhouetted leather boot, modeled off an Edwardian Woman's riding shoe. The typographical design therefore becomes a conflict of signifiers of the masculine and the feminine. 


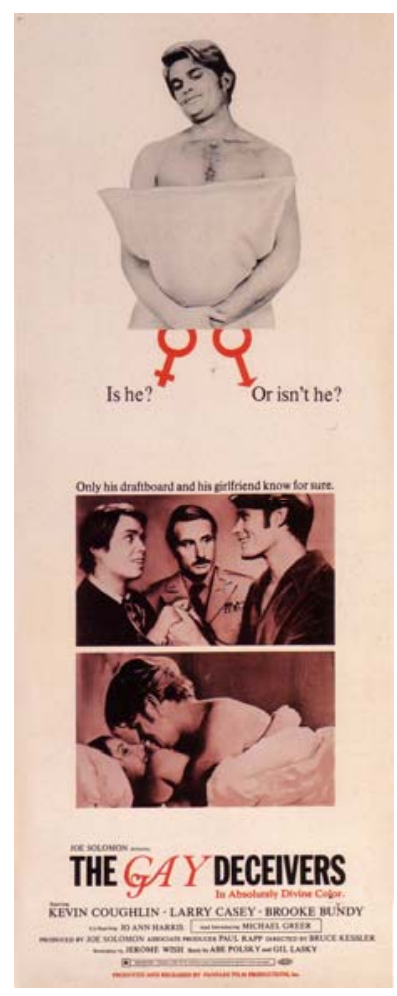

Figure 3. Promotional poster for The Gay Deceivers (1969). This

straight-masquerading-as-gay film placed heavy emphasis on mincing and swishing as two heterosexual men pretended to be homosexual in an effort to avoid the draft. In the title design the dichotomy between the masculinsed 'straight' and the feminised 'gay' is actualised by pitching a bold, realist sans serif face (Franklin Gothic extra condensed) against a typographically effete treatment of the word 'gay' (Fairfield2 56SwhMedit OSF).

In historical constructions of gay identity, the internally discordant has often been created by opposing antithetical signifiers of gender. The approach uses a heightened sense of contrast to underscore dysfunction. In a significant number of historical promotional posters for films about gay men one can identify feminised and hyper-masculinised typefaces interfaced within the same design. Examples of this are epitomised in title designs for films like Glen or Glenda (Edward D. Wood Jr, 1953), The Leather Boys (Sidney Furie, 1964), (figure 2), The Gay Deceivers (Bruce Kessler, 1969) (figure 3), and much later, The Adventures of Priscilla Queen of the Desert (Stephan Elliott, 1994).

\subsection{The damaged threat}

While the construction of the discordant may be seen as a generic approach to typographic portrayals of gay identity, in the 1960s a more overt employment of type as a signifier of disturbance was also in evidence. In this period a significant amount of promotional material for films about gay men orchestrated distressed or damaged letterforms, tabloid styling, or destabilised titles constructed in torn environments.

When Compulsion (Richard Fleischer) and Suddenly Last Summer (Joseph Mankiewicz) were 
released in 1959, they were Hollywood's first mainstream dramas dealing directly with gay men as major characters. Both profiled disturbingly negative portrayals.

Display faces used in these films, as well as a number that followed in their wake: [Victim (Basil Dearden, 1961), The Leather Boys (Sidney Furie, 1964), Fortune in Men's Eyes (Harvey Hart, 1971) and Los Placeres Ocultos (Eloy de la Iglesia, 1977)] all represented 'gayness' as dangerous, atypical, or dysfunctional. Typographical representations of the 'queer' male profiled disrupted kerning, dominant letterforms (often torn or placed at irregular angles to each other) and copy and display faces working in collusion to communicate a tortured psychology of instability and threat.
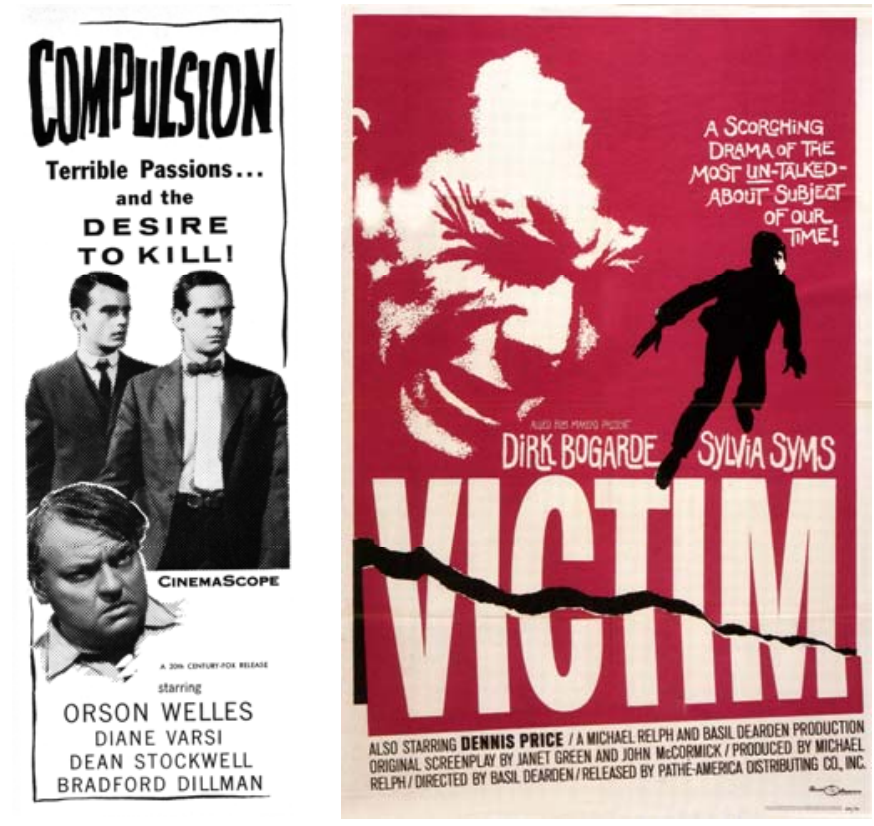

Figures 4 \& 5. Display faces for Compulsion (1959) and Victim (1961). While there is a significant difference in the quality of these designs, both use type to complement expressions of anxiety. The display faces and, in Victim, the supporting type, are constructed as unstable. Both designs conform to the dominant typographic approach to queer themed films of the period in their use of bold, damaged, sensationalised, or displaced letterforms.

Tortured as they were, the gay men of these print media campaigns were also sensationalised. Titles and taglines were generally large, uppercase, and tabloid-like in form. Supporting imagery was normally black and white with deliberately low production values used to suggest the tawdry nature of the subject.

\subsection{The passive and passive-aggressive}

However, if a tabloid ethos permeated typographical depictions of gay men in the middle decades of last century, it was to be disrupted by an almost antithetical propensity for passive lettering as the voice of the gay man, as he progressed into the 1970s and 80s. At this time, 
there surfaced an increasing number of queer film titles designed using non-capitalised forms.

The non-capitalisation of the other is an interesting phenomenon. It has precedents that may be traced back to the historical marginalisation of cultural minorities. In standard English usage, the proper names of national groups are traditionally marked with a capital letter. However, up until the ideological debates surrounding the American Reconstruction, the word Negro was always written with a lower case initial. (Note 4) While this approach to framing the ethnic-other eventually became unacceptable, the same employment of lowercase type to demarcate the otherness of gay men continues to function as a signifier today.

In film titles, non-capitalised queer identity appears to have surfaced through designs for gay and bisexual pornography. (Note 5) An early example of this approach may be evidenced in the one-sheet designed for the release of Pink Narcissus (Jim Bidgood, 1971) (figure 6). In this poster, type is delicate and affected. The submissive lowercase is used to present gayness as something essentially passive.

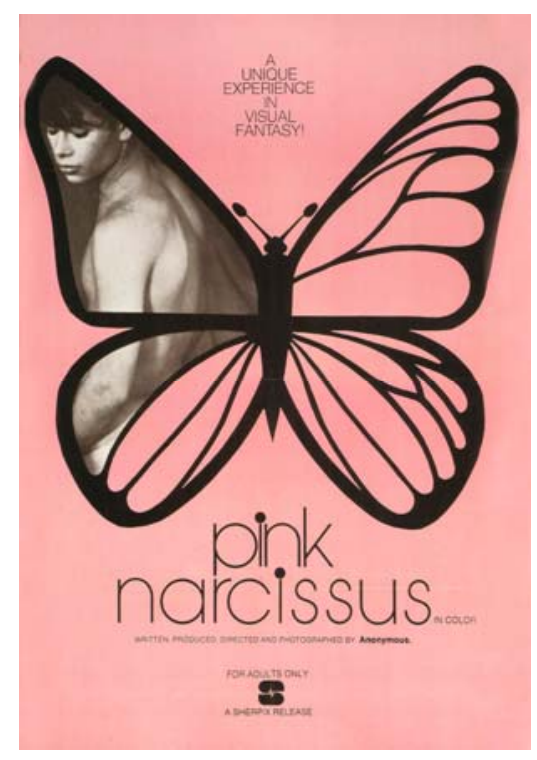

Figure 6. This two-colour print for Bidgood's Pink Narcissus was used to promote an 8mm U.S. production, released in 1971 without the director's consent. The film featured a young male prostitute visualising a range of erotic fantasies.

The propensity for a quiet, lowercase gay voice continues to profile today in a number of posters for contemporary Asian films. Indicative of these are promotional posters for gay themed productions like Happy Together (Wong Kar-wai, 1997), Drift (Quentin Lee, 2002), and Cut Sleeve Boys (Ray Yeung, 2006). However, while the sometimes delicate treatment of the gay voice in these films protects a submissive quietness, in much European and American queer cinema of the 1990s and early 2000s, the passive lowercase title underwent a distinctive typographic metamorphosis. Its passivity became aggressive.

Passive-aggressive titles contradict their submissive, lowercase voices with bold, often powerfully coloured, sans serif typefaces. These typographical treatments are constructed as 'out'. They create tension through discord. In this regard they are paradoxes. They exploit the 
contradiction between strong letterforms and lowercase reticence.

Passive-aggressive title design may be traced back to films like Warhol's Lonesome Cowboys (1968), and X rated gay men's productions like Tom De Simone's Station to Station (1974). However, the passive-aggressive appears to have gathered confidence and strength through increasingly mainstream titles that can be traced chronologically through films like Paris is Burning (Jennie Livingston, 1990), The Celluloid Closet (Rob Epstein and Jeffrey Friedman, 1995), Ma Vie en Rose (Alain Berliner, 1997), Kiss Me Guido (Tony Vitale, 1997), Edge of Seventeen (David Moreton, 1998), Latter Days (C. Jay Cox, 2003), A Touch of Pink (Ian Iqbal Rashid, 2004), Garcon Stupide (Lionel Baier, 2004), and Brüno (Larry Charles, 2009).

Passive aggression as a typographic paradigm perhaps reached a design apotheosis with the powerful title designs created for Simon Shore's Get Real (1998) and Ana Kokkino's Head On (1998), (figures $7 \& 8$ ). These designs, both released in 1998, profile a highly assertive queer voice that is both submissive and aggressive. Both confront with bold, clear, sans serif faces, yet the designs profile an internal tension. This is not the testosterone voice of the hyper-masculine. It is another kind of assertiveness; confident, self-possessed, but essentially speaking in a different tone. It clearly speaks of another kind of assertiveness.
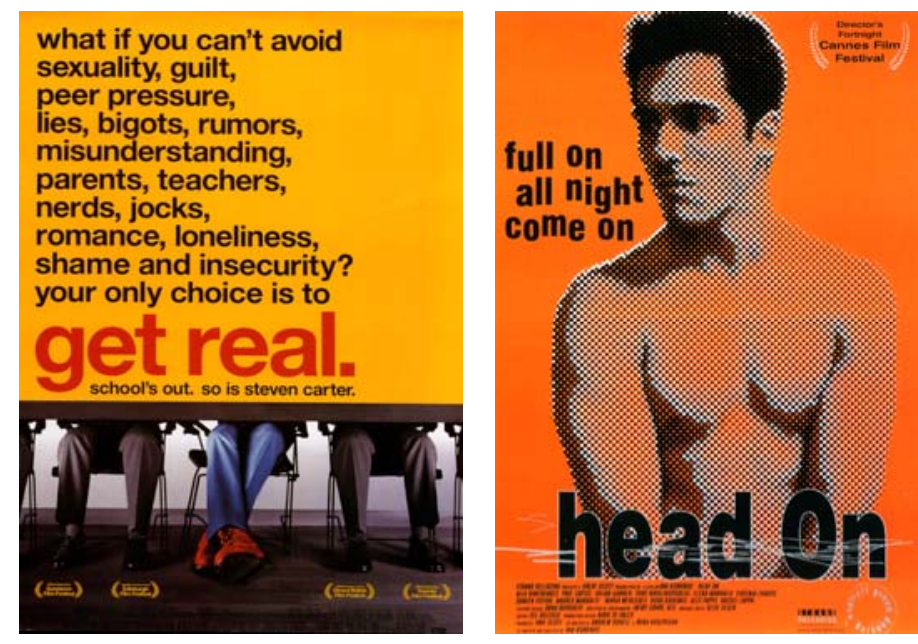

Figures $7 \&$ 8. Promotional posters for Simon Shore's Get Real (1998) and Ana Kokkino’s Head On (1998).

\section{Designing the queer voice in boy}

\subsection{Authenticity}

Salen (2001) suggests "spaces of cultural inclusion and exclusion are mediated via typographic form" (p.132). In discussing those who fall outside of the normalising boundaries of linguistic standardisation, she argues that distinctions in typographic form 'display' otherness and in their construction are reliant upon "the historicising mechanics of cultural standardisation" (ibid.).

Considering a history in film of 'displaying' gay identity as transgressive and 'othered', I was 
faced as a designer with a question. How, in a film that used type as its system of monologue might one authentically create the voice of a young, gay protagonist?

The film boy is set in New Zealand. The protagonist is a 15-year-old male prostitute called Sam. He lives a life that is made up of two conflicting worlds. The first comprises the overground. This is the evident world of the small town with its socially demarcated school, watchful streets, local hotel and undercurrent of comfortable brutality. Here Sam exists as the beloved child of his grandmother, as a loner, and as a mild eccentric with a strange penchant for collecting broken dolls and refuse from the local dump. Like many gay boys he exists in this world as a discrete character, hiding all traces of his parallel life.

The film's second world unfolds in a completely separate environment. This is the cultural space of the public toilet. Here Sam cruises in the weekends and after school. He turns tricks (has sex for money), knows many of the men in the town, knows how to avoid the police, and has learned a complex language and associated rituals that are beyond the comprehension of most of the overground community.

\subsection{The argot and the 'visual sound' of boy.}

In New Zealand, the argot that partially narrates Sam's story is a savage and self-denigrating language evidenced among some bog cruisers and in the slang of male prostitutes working in the country's larger cities. Because Sam lives in a world of secrecy he narrates his story in a silent voice. Like many young sex workers his underground life is kept scrupulously quiet. His intimate sexual contact with others is silent, his contemplation is silent, even his attacks on those who hurt him are silent. As a result his narration is pitched at a level closer to the safety of internal thought than the confidence of projected speech (Note 6).

In designing the 'visual sound' of the voice for this film, I sought to reach beyond established conventions of 'queer' type in cinema to draw upon something less well known, yet infinitely more substantial. I tried to create voices from thematic profiles evident in the actual speech that Sam knew in the world of the bogs (toilets). By doing this I was attempting to draw on a body of knowledge that might inform design considerations beyond the clichéd convention profiled in many gay themed film titles. Building on research I had undertaken into the history of the male prostitute's argot in New Zealand, I considered two dominant themes evident in the argot; detachment and ecclesiasticism.

\subsection{Detachment}

In general, sex between men in public toilets is silent and detached. Rituals of contact, although complex, are enacted using a series of highly engineered cues and responses. Written notes, displays through glory holes, the sounds of toilet paper being rapidly pulled from dispensers, coughing, and the shuffling of feet, all operate as signals for contact and all replace the intimacy of speech. Foucault, when discussing this detachment in the attraction of anonymous sex between men says, "you stop being imprisoned inside your own face, your own past, your own identity. It's not the assertion of identity that is important; it's the 
assertion of non-identity," (Foucault, 1978, cited in Macey, 1993, p. xv).

This non-identity in 'bog cruising' is also evident in specific linguistic profiles of the argot. One of its significant features is its detaching of identity through the use of the third person singular pronoun to describe other men. This quality of the language frames men as objects. The propensity for calling members of one's community 'it' or 'that thing', or referring to a partner as a 'trick', 'number', 'trade', or 'meat', is part of a profile of oppression where the marginalised other self-represses through the detachment and dehumanisation of his peers. Mount in his introduction to Rogers' (1972) The Queens' vernacular: A gay lexicon, notes that early gay slang, “... demonstrates self pity and downright masochism with which gay people have forged the common language into a means of communicating their experience... [here] the oppressed deal with... the pleasure and tension that results from living a secret life. Much of it is more vulgar, barbaric, cruel, racist and sexist than any speech you will ever encounter" (p. ii).

The argot of the male prostitute is an ornate but angry language. It is savage and witty and dehumanising in many of its constructions. The nexus between its detachment and anger was a challenge to interpret in type. The language demonstrates a clear hostility to regulatory and punitive agencies but it is also scornful of clients and other sex workers.

Cage (2003), in discussing gay slang in South Africa, talks about this as a form of linguistic, dehumanised detachment where, "people are not viewed as individuals when referred to... but are relegated to the level of sexually consumable commodities, without hopes, feelings and needs. They merely become featureless units in a noxious swarm of past, present and potential sex partners" (pp. 31-32).

The letterforms used in boy were constructed from dictionary collages, old Letraset and overlapping layers of sellotape. When animated as plates these flickered angrily and disappeared. For each word there were three separate plates, each containing a subtly different alignment of letters. These plates replaced each other on average three times, across four to ten frames. They flickered so fast that any single plate was unidentifiable but in composite one sees a vibrating word for approximately .8 of a second. The animation of layers of type was used to enhance the film's detached voice in the way that paralinguistics augment speech. This expansion of the normal syntactic abilities of type gives the written voice in the film a brittle anger. The detachment bristles and crackles. It has an undercurrent of emotion that speaks in short, pithy statements.

The placement of this type in the film, specifically in the bog sequences, references the way that the written word operates on toilet walls. The type is not uniform, it is unsettled on the substrate's surface. It is bold but often in a state of decomposition. The writing is clear and unclear. On a toilet wall, due to the vigilance of cleaners and local council caretakers, written text is often partially erased. In the film this erasure is temporal. The words vibrate irritably, establish themselves, and are gone. They are an impression, an angry mark that is seen and quickly removed. The argot flickers in and out of the time that Sam spends waiting for a trick. 


\section{Macrothink}

It forms around him as an angry but ephemeral commentary, (figures 9-12).
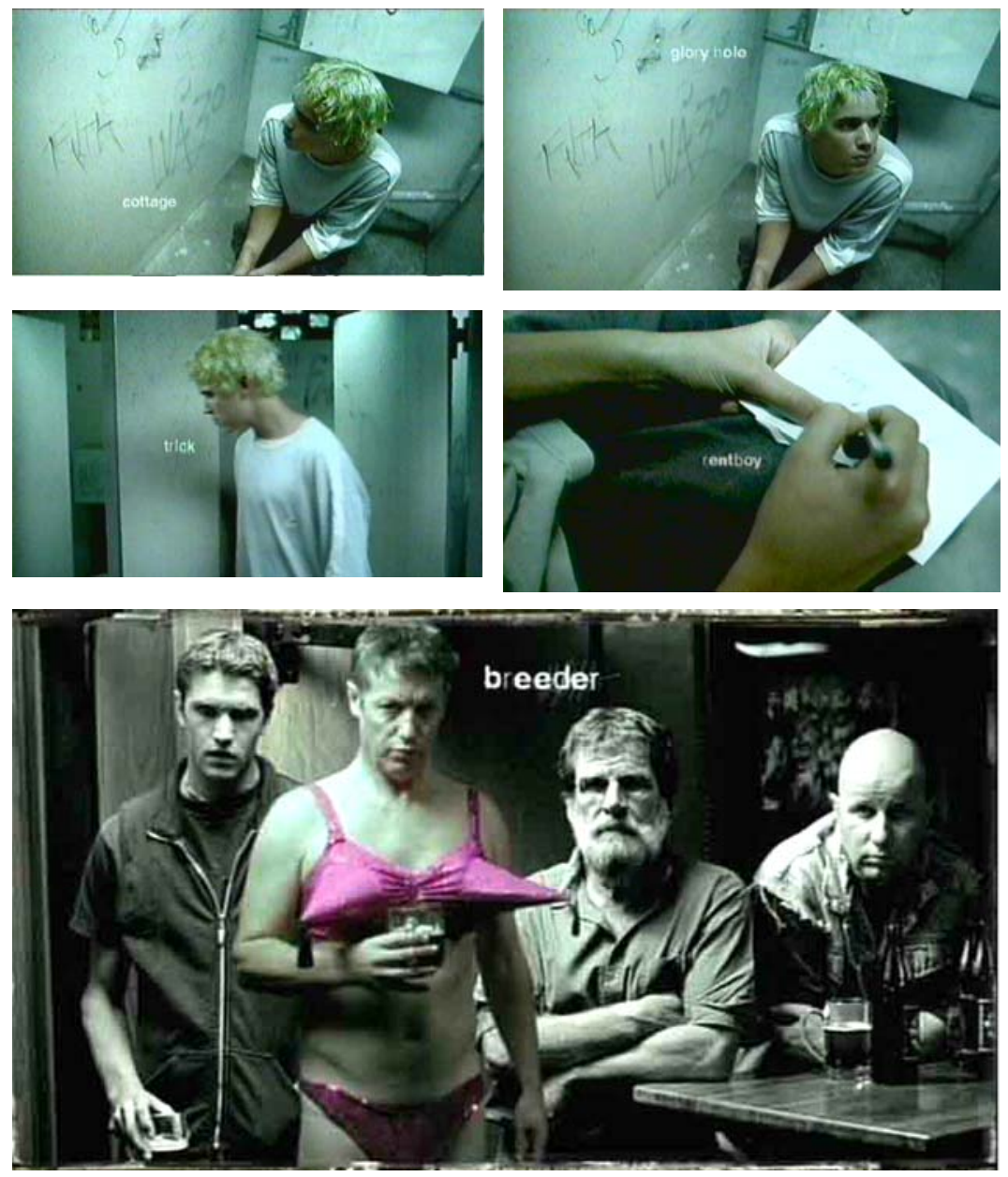

Figures 9-13. Stills of Sam's use of the detached typeface. Because of this unit-frame ratio, single or compound words are recognised as fleeting but emotionally charged intrusions in

the visual narrative. They appear and disappear like half-captured thoughts. In some sequences, the three versions of each word have built into the animation an extra plate that contains a scratched background. This addition was used to add hostility and appears in the insults smeg [heterosexual], breeder [married man], and fish [woman] that Sam hurls at people who hurt him.

\subsection{Ecclesiasticism}

\subsubsection{The poetic ecclesiastical}

However, if detachment is the voice of anger in the story, it is offset by a second typographic treatment that appears in the film's prologue and title sequence. This voice is very different to the brittle detached one we have just considered. It is heterodiegetic and resurfaces spasmodically throughout the film's narrative. This second voice drifts and fades in a manner designed to imitate the grace of contemplative thought. It is vulnerable, ornate, eclectic, and quietly repetitive. Rather than crackling across the plane of the film, it is wiped on and off by the movement of imagery. Yet this typographical voice also drew its inspiration from the 
argot. Its design was sourced in the language's distinctive engagement with the ecclesiastical.

This phenomenon, while evident is rarely discussed in analyses of gay men's language.

\subsubsection{Historical contexts}

Ecclesiastical metaphors may be found in the argot of the male sex worker in specific terms like glory hole (a hole in the wall between two toilet cubicles); having church (to kneel in order to perform oral sex); Christ and the two apostles (a dated expression for the genitals of prudish or shy men); and in the names of specific toilets like the Chapel (Pitt Street, Auckland); the Catacombs (Auckland Museum); the Grotto (Durham Street East in Auckland); and The Wailing Wall (Sydney Hospital in Kings Cross). In terms of arrests in public toilets, the same metaphor profiles in terms like genuflecting for Maria (being bundled into a police car); a demon (a plain clothes detective); and Our Lady of the Golden Brooch (an arresting, uniformed officer).

Because one of the most actively oppressive agencies involved in the persecution of gay men has been the church, it is not surprising that ecclesiastical features have been recontextualised and parodied in language forms like Polari and Gayle (Note 7) and the argot of the male sex worker.

This parodying of the ecclesiastical is a significant feature of the queer activism of groups like the Sisters of Perpetual Indulgence. (Note 8) Noted both for their politicising of gay and lesbian oppression and their linguistically revivalist rituals, chapters undertook a wide range of initiatives in the latter part of the twentieth century, including the revival of High Polari and its use in a camp translation of the King James version of the Bible (Note 9).

However, phenomena like the Sisters of Perpetual Indulgence may be seen merely as part of a historical continuum of ecclesiastical parody. Gay men's reconstitution of Christian ritual has historical precedents dating as far back as the working class Molly Houses of the eighteenth century. These were taverns and clubs where men met to have sex with other men. Norton (1992) refers to Molly 'marriages' that occurred in these establishments when two men paired off and had sex in another room known as the Chapel. He also offers a description of a 'lying in' where a wooden baby was christened after being mock birthed between a man's legs.

\subsubsection{Ecclesiasticism in the film boy}

Thus, in boy we see this ecclesiasticism permeating both image and text. It appears in the structure of the film's closing scene as a reference to Andrea Del Castagno's Last Supper. We see bedroom walls obsessed with votives. We see angels made of decayed dolls. Most significantly however, we see Sam's silent voice talking about catechisms, his mother's death and blessings of grace, as something lyrical that is embellished with fading scrolls and ecclesiastical flourishes.

The letterforms of his voice are borrowed from across Zuzano Liko's font family Mrs Eaves (1996), but the treatment is eclectic and decontextalised. Capitals, italics and regular letters 


\section{Macrothink Institute ${ }^{\mathrm{TM}}$}

are cobbled together in the same way that parody of ecclesiasticism juxtaposes and recontextualises to create meaning. The distorted kerning in each word and the integration of varying postures enable a design where eclecticism breathes with its own distinctive life. Behind these forms is animated a subtle shadow. This gives the words a level of drifting movement designed to parallel the pace of the images moving around them.

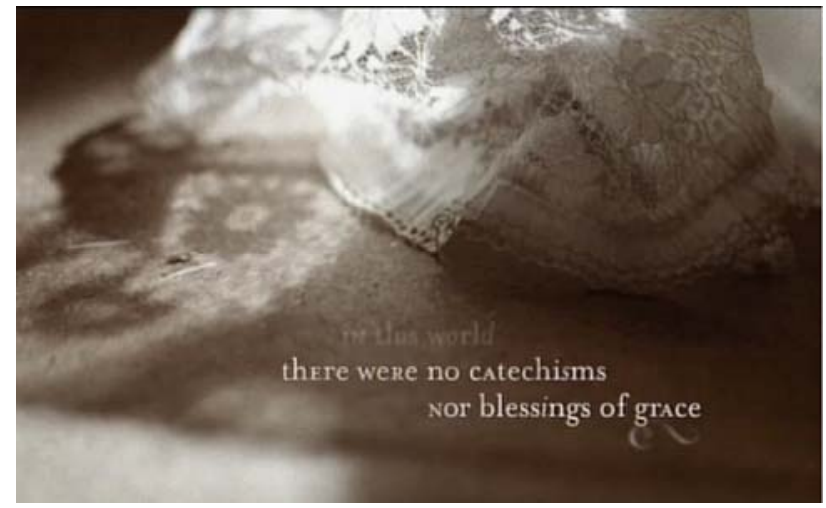

Figure 14. Opening poem letterforms. Words are constructed as ornamental forms using a variety of replaceable upper and lower case letters, normal and italicised forms and animated (dislocatable) flourishes. An analysis of the still demonstrates how both upper and lowercase versions of the letters $n[N]$, e [E] and $r$ [R] are integrated in different ways in each word. The result affords a delicate but highly legible voice, one that drifts, repeats and floats with the rhythm of an interior prayer.

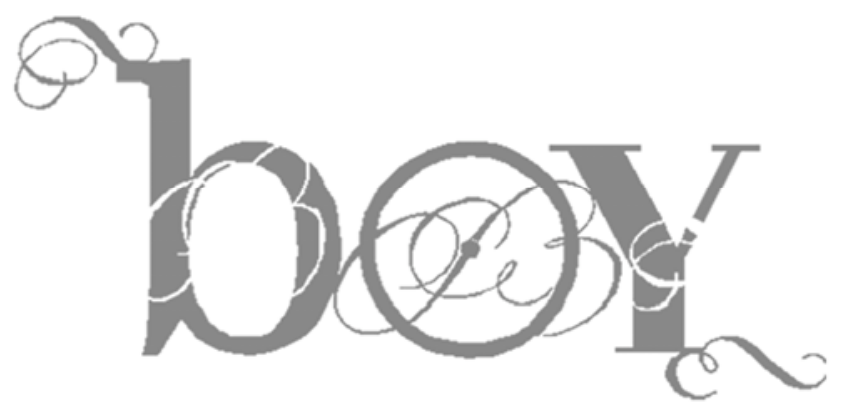

Figure 15. Title graphic. The type features a fill and three individual embellishments that connect the letters in an almost calligraphic fashion. The ascender on the lowercase $b$ reinforces the singularity and immaturity of the boy and also references his vulnerability.

This same ecclesiasticism is evidenced in the film's title design. Here upper and lowercase letterforms are borrowed from three opposing font families. This is not passive aggression but Sam's eclectic youth. It is a word strung together by fragile flourishes that both embellish and subtract. The title isn't tabloid; it is quietly ornate. It is a gay design for a gay film that seeks to create cohesion by combining the disparate. It gathers meaning from different worlds. It seeks poetry in the dislocated. 


\section{Conclusion}

Since the turn of the century, despite a growing corpus of research on gay men's language forms (Baker, 2002a; Baker, 2002b; Baker \& Stanley, 2002; Cage, 2003; Denning, 2007; Ings, 2007; Ings, 2010), discourse surrounding the specific nature of their argots as they relate to the visual materiality of language is almost non-existent. If one accepts Crystal's (1997) assertion that "typographic features cause a change in linguistic meaning" (p.13), then we are left with rich territory for creative and analytical interrogation.

The typographic treatments created for the film boy responded to the world of a young male sex worker. Type is a carefully constructed contribution to the film's aesthetic and cultural integrity. It speaks as thought, and draws its forms and expressions from the core of the film's diegesis.

The typographer seeking to address clichéd voices designed to speak for a particular queer identity in film is faced with an established practice of intertextual borrowing. Queer film has a history of exoticisation, camp emasculation, double-entendre and damaged brutalism. While these profiles are often critiqued in terms of character and narrative in cinema, little attention has been paid to how the written voice of film has reinforced or helped to embed these values. In movie posters and title sequences, a cultural standardisation built on notions of the other and reinforced by decades of intertextual cliché has produced a range of gay voices that are generally more affectations than cultural insights.

As we bridge spaces between linguistics, typography and cultural signification, we are offered useful ground for considering the implications of film's ability to 'brand' not only its texts but also the identities it purports to represent. In this consideration it is sometimes useful for creative practitioners to bridge gaps between linguistics and typography. By doing this they may offer insight into the nature of their texts and reveal something of the purposeful, politicised, and deliberated nature of design.

\section{References}

Allen, I. (1990). Unkind words: Ethnic labeling from Redskin to Wasp. New York, NY: Bergin St Garvey.

Baker, P. (2002a). Fantabulosa: A Dictionary of Polari and Gay Slang. London, England: Continuum.

Baker, P. (2002b). Polari: The Lost Language of Gay Men. London, England: Routledge.

Baker, J. P. \& Stanley, J. (2002). Hello Sailor! Seafaring Life for Gay Men 1945-1990. London, England: Pearson.

Bellantoni, J., \& Woolman, M. (1999). Type in motion. Innovations in digital graphics. London, England: Thames \& Hudson.

Bellantoni, J., \& Woolman, M. (2000). Moving type: Designing for time and space. Hove, 
England: Rotovision.

Cage, K. (1999). An investigation of the form and function of language used by gay men in South Africa. (Unpublished master's thesis). Rand Afrikaans University, Johannesburg, South Africa.

Cage, K. (2003). Gayle. The language of Kinks and Queens: A dictionary of gay language in South Africa. Johannesburg, South Africa: Jacana Media.

Cohen, S. (1999). Tea with Mother Abyss. [Online] Available: http://www.q.co.za/regulars/cohen/991124-sisindulgence.htm(April 8, 2011)

Crystal, D. (1997). Towards a typographical linguistics. Type, 2(1), 7-23.

Denning, C. (2007). Polari. [Online] Available: http://www.chris-d.net/polari(May 10, 2011)

Drucker, J. (1984). Letterpress language: Typography as a medium for the visual representation of language. Leonardo, 17(1), 8-16.

Griffith, R., \& Mayer, A. (1971). The movies. New York, NY: Spring Books.

Ings, W. (2007). A matter of convenience: Discourses between physical, legal and linguistic frameworks impacting on the New Zealand Public toilet. [Online] Available: http://epress.lib.uts.edu.au/ojs/index.php/publicspace/article/viewFile/544/412

Ings, W. (2010). Trolling the beat to working the soob: Changes in the language of the male sex worker in New Zealand. International Journal of Lexicography. [Online] Available: http://ijl.oxfordjournals.org/content/early/2010/02/01/ijl.ecp038.full.pdf+html doi:10.1093/ijl/ecp038

Kress, G., \& Van Leeuwen, T. (1996). Reading images: The grammar of visual design. London, England: Routledge.

Macey, D. (1993). The lives of Michael Forcault. London, England: Vintage.

Mealing, S. (2003). Value added text: Where graphic design meets paralinguistics. Visible Language, 37(1), 42-57.

Norton, R. (1992). Mother Clap's Molly house. The gay subculture in England. London, England: GMP Publishers.

Rogers, B. (1972). The Queens'vernacular: A gay lexicon. San Francisco: Straight Arrow Books.

Salen, K. (2001). Surrogate multiplicities: Typography in the age of invisibility. Visible Language, 35(2), 132-153.

Spitzmüller, J. (2007). Visible by design: The significance of typography in media communication.

Available:

http://www.hituzi.co.jp/kenkyukai/happyo-rejume/Spitzmueller2Mar07_2.pdf 
Waller, R. (1996). Typography and Discourse. In R. Barr, M. L. Kamil, P. Mosenthal, \& P. D. Pearson (Eds.), Handbook of Reading Research, Volume 2 (pp. 341-380). New Jersey, NJ: Lawrence Erlbaum Associates.

Walker, S. (2001). Typography and language in everyday life: prescriptions and practices. London, England: Language in Social Life Series

Worthington, M. (1998). The new seduction: Moveable type. AIGA Journal, 16(3), 9-10.

\section{References for images}

Compulsion [Movie poster]. (1959). United States: $20^{\text {th }}$ Century Fox.

Get real [Movie poster]. (1998). United Kingdom: Paramount Classics.

Head On [Movie poster]. (1998). Australia: Strand Releasing.

Ings, W. (Director). (2004). Boy [Film stills]. New Zealand: Room 8 Productions.

Ings, W. (Designer). (2004). Boy [Title graphic]. New Zealand: Room 8 Productions.

Leather Boys [Movie poster]. (1964). United Kingdom: Allied Artists Pictures Corporation.

Pink Narcissus [Movie poster]. (1971). United States: Sherpix.

The Gay Deceivers [Movie poster]. (1969). United States: Fanfare Films Inc.

Victim [Movie poster]. (1961). United States: Rank Film Organisation/Pathé-America Distributing Company.

Wanderer of the West [Key card]. (1927). United States: Trem Carr Productions.

\section{Notes}

Note 1. Boy is a silent film about a young male prostitute in a small New Zealand town who discovers the truth behind a fatal hit and run accident. The film was released in June 2004. It was short-listed for the 2006 Academy Awards after winning Cinequest, and the Berlin Short Film Festival (Interfilm). The film was officially selected for fifty-three international film festivals between 2004 and 2006.

Note 2. The argot is made up of four forms: words deriving from thieves' cant, Polari, (an argot used by gay men in the United Kingdom), gay slang, and terms relating to specific locations, events or groups of people. For a broader discussion of the language form, its development and metaphors, see: Ings, W. (2010). Trolling the beat to working the soob: Changes in the language of the male sex worker in New Zealand. International Journal of Lexicography. ijl.oxfordjournals.org/content/23/1/55.full.pdf

Note 3. In arguing this point Spitzmüller alludes to the role of calligraphy in such cultures and phenomena like the logographic Japanese Kanji system.

Note 4. See Allen, I. (1990). Unkind Words: Ethnic Labeling from Redskin to Wasp. New 
York: Bergin St Garvey (p. 74.1).

Note 5. Examples can be found in soft-core queer porn films like Threesome (Lee Beale, 1970) and Score (Radley Metzger, 1973).

Note 6 . Therefore the temporal duration of type breaks with recommended industry ratios of seven to ten seconds visibility on screen. This renegotiated pace enables us to 'read' in a manner no longer associated with the translation of the spoken word. What we encounter is the pace of internal thought, its fleeting impression or drifting vagueness.

Note 7. Gayle is a term given to the distinctive South African gay men's argot. It contains many ecclesiastical terms locatable in British Polari and the argot of the male sex worker, but it also contains words originating from the moffie drag culture of the Western Cape.

Note 8. While associated strongly with San Francisco and Sydney, the New Zealand chapter of this order first made an appearance in the Wellington Gay Pride Week in 1984. The chapter was called The Sisters of Sodomy. While the New Zealand chapters had relatively short-lived profiles, their Sydney and San Francisco equivalents were prominent in the early 1980s. The Australian chapter, included Sisters Sit-On-My-Face, Third Secret of Fatima, Joy of Man's Desiring, Fuck-Me-Silly, Fellatio Obliviata, and Mary Azaria-in-a-pram. Mother Inferior, [later known as Mother Abyss aka Fabian Loschiavo], was the most prominent of the sisters and was noted for political events like performing a formal exorcism at the Gates of Parliament on March 29th 1982. Mother Abyss also walked the highly documented tour of 'Gay Sydney', dressed in a pink habit, singing Volare, accompanying herself on a squeeze box and being preceded by a holy relic of gay matrimony, the urinal from a destroyed popular cruising toilet, "where so many unions were consecrated." (Cohen, 1999, p. 4).

Note 9. See www.thesisters.demon.co.uk/bible/introduction.html

\section{Glossary}

Ascender: The section of a lowercase letter (such as b, d, and k) that ascends above the $\mathrm{x}$-height of other lowercase letters in a face.

Body copy: The main text in a publication. Body copy traditionally excludes titles, subheadings, and captions.

Descender: The section of a lowercase letter (such as p, q, and y) that descends below the baseline of other lowercase letters in a face.

Display face: A face that has been designed to work at large point sizes. It is often used in headlines and titles. Normally these faces are not as readable at smaller sizes or when presented as large bodies of text.

Font family: A collection of faces designed so they can be used together. For example, the Times family consists of roman and italic styles, as well as regular and bold weights. Each weight and style combination in a family is called a face. 


\section{Macrothink}

International Journal of Linguistics

ISSN 1948-5425

2011, Vol. 3, No. 1: E16

Kerning: The fine adjustment of space between individual characters in a line of text. The aim of kerning is to visually equalise spaces between letters so that the eye moves easily along the text.

Leading: The amount of space created between lines of text. Closer leading fits more text on a page, but decreases legibility. Looser leading spreads text out.

One sheet: In the entertainment industry a one sheet is a synonym for poster artwork. However, the term specifically refers to a single document that summarises a film for publicity and sales. A one sheet measured 27" x 41" before 1985, and 27" x 40" after that date.

Sans serif: A typeface that does not feature serifs.

X-height: The height of the lowercase letter $\mathrm{x}$, but (excluding the ascenders and descenders), it is also the height of lowercase letters in a font. The $\mathrm{x}$-height may vary between typefaces at the same point size.

\section{Copyright Disclaimer}

Copyright is reserved by the author.

This article is an open-access article distributed under the terms and conditions of the Creative Commons Attribution license (http://creativecommons.org/licenses/by/3.0/). 